\title{
Solitary Synchronous Metastasis to the Urinary Bladder from Renal Cell Carcinoma: A Case Report
}

\section{Renal Hücreli Karsinomdan Mesaneye Soliter Senkron Metastaz: Olgu Sunumu}

\author{
Abidin TUNA', Burçin TUNA², Mustafa SEÇíL ${ }^{3}$, Aydın ŞAHINN ${ }^{4}$, Kutsal YÖRÜKOĞLU² \\ Departments of ${ }^{1}$ Urology and ${ }^{4}$ Pathology, M.H. Seyfi Demirsoy State Hospital, ${ }^{2}$ Pathology and ${ }^{3}$ Radiology, Dokuz Eylül University, Faculty of Medicine, \\ IZMIR, TURKEY
}

\begin{abstract}
Renal cell carcinoma metastatic to the urinary bladder is a rare entity. Few cases of renal cell carcinoma with solitary synchronous metastasis to the urinary bladder have been reported. We report a case of renal cell carcinoma with solitary synchronous metastasis to the urinary bladder. A new metastasis developed in the right adrenal gland at the 24 th month, and was resected. The patient is alive without any new recurrences or metastasis 36 months after the initial diagnosis. The follow up duration of our case is the longest of published cases.
\end{abstract}

Key Words: Metastasis, Prognosis, Renal cell carcinoma, Urinary bladder

\section{ÖZ}

Renal hücreli karsinomun mesaneye metastazı oldukça seyrek olup az sayıda olgu rapor edilmiştir. Mesaneye soliter senkron metastaz yapan renal hücreli karsinom olgusunu rapor ettik. Olguda 24. ayda sağ adrenalde yeni metastaz gelişti ve çıkarıldı. İlk tanıdan itibaren 36. ayında olan olgu yaşıyor ve herhangi bir yeni nüks ya da metastazı yoktur. Olgumuz yayınlamış olguların takip süresi en uzun olanıdır.

Anahtar Sözcükler: Metastaz, Prognoz, Renal hücreli karsinom, Mesane

The urinary bladder is not a common site of metastasis for RCC. A solitary urinary bladder metastasis from RCC has only rarely been described. To our knowledge there are less than five cases of synchronous solitary metastasis of renal cell carcinoma to the urinary bladder including ours.

\section{CASE REPORT}

tissue (2). Urinary bladder is an extremely unusual site of metastasis, and was only mentioned in a few case reports (3-5).

The prognosis of metastatic RCC is poor and seems not to be related to the type of treatment. It has been reported that patients with metastatic RCC and a solitary metastasis may benefit from nephrectomy with resection of the metastatic lesion (6). In general, an improved prognosis has been observed when the solitary resected metastatic lesion involved the lung, adrenal gland, or brain (7). Many reports suggest that surgical resection is the choice of treatment for bladder metastasis because it is more effective than other treatment modalities including chemotherapy and immunotherapy $(3,5,8)$.
A 57-year-old man was referred to our hospital with a painless macroscopic hematuria. Ultrasonography showed a solitary large bladder tumor and a right renal mass. Computed tomography revealed a large tumor at the mid-portion of the right kidney and a polypoid mass originating from the left lateral wall of the bladder. (Figures 1,2). Cystoscopy revealed a solitary, non-papillary tumor in the urinary bladder. Right radical nephrectomy and transurethral resection of the bladder tumor were performed since there were no other systemic metastases. Histopathological diagnosis of the renal tumor was renal cell carcinoma (clear cell carcinoma, Fuhrman grade 2, pT2) (Figure 3). Histological examination revealed that the

Correspondence: Burçin TUNA

Department of Pathology, Dokuz Eylül University, Faculty of Medicine, IZMİR, TURKEY

E-mail: burcin.tuna@deu.edu.tr Phone: +90 2324123411 
bladder tumor was clear cell carcinoma similar to the right renal tumor. The morphology and immunohistochemical staining profile of the bladder tumor was the same as the primary renal tumor (positive staining with pancytokeratin, cytokeratin 7, CD10 and vimentin, and negative staining with cytokeratin 20 , chromogranin and high molecular weight keratin) (Figure 4A-C). The tumor cells were of the same grade (Fuhrman grade 2) as the primary tumor. The case was therefore accepted as solitary synchronous metastasis to urinary bladder from RCC. Adjunctive therapy was given postoperatively (Interferon alpha-2a; 9 million unit, 3/week). The patient was well until right surrenal metastasis developed at 24 months of follow-up. Right adrenalectomy was performed, and the tumor was diagnosed as RCC metastasis. The patient is alive without any new recurrences at 36 months.

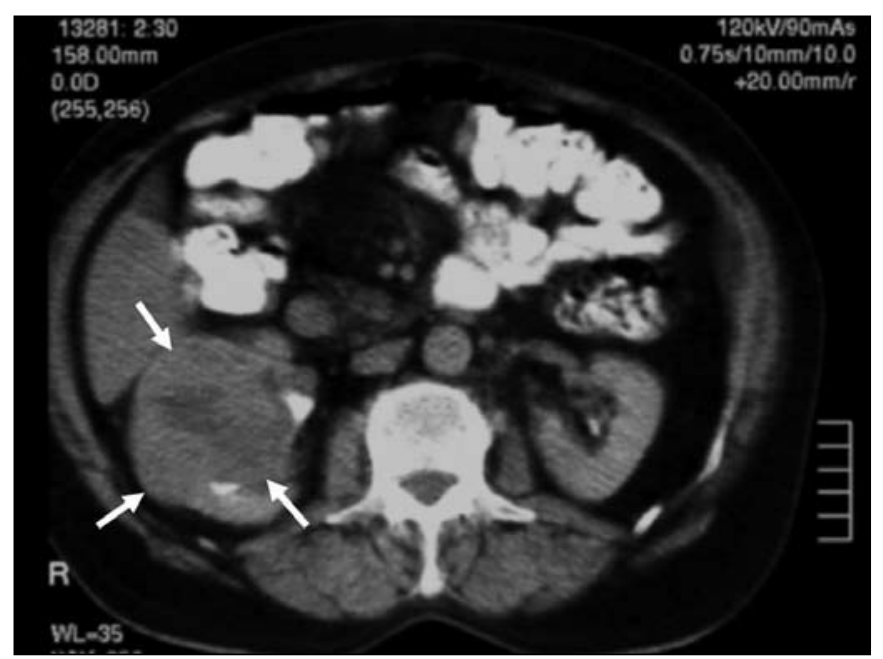

Figure 1: A solid renal mass is observed at the mid-portion of the right kidney (arrows).

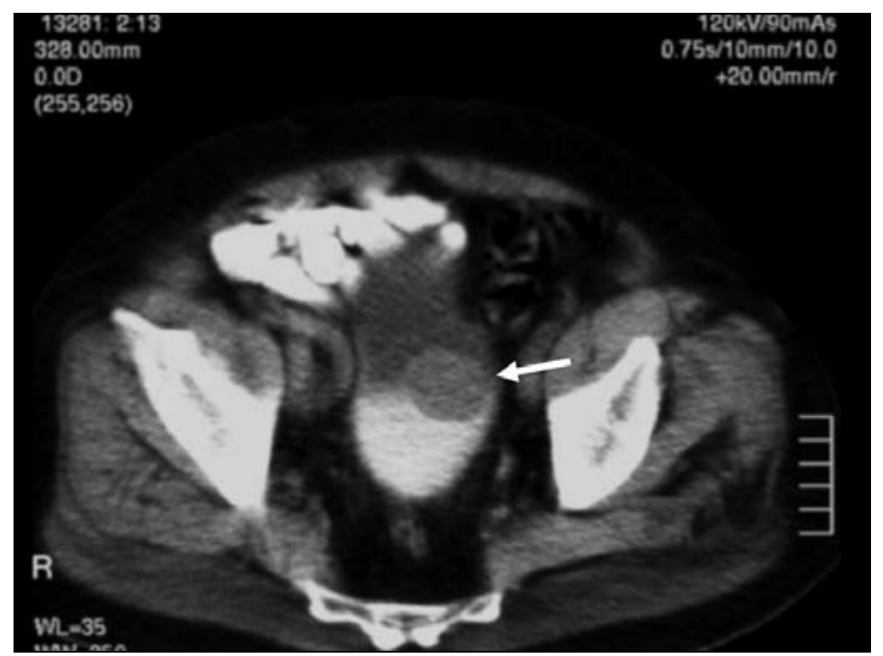

Figure 2: A polypoid mass originating from the left lateral wall of the bladder is seen (arrow).

\section{DISCUSSION}

RCC is a tumor with an unpredictable clinical course and behavior. Metastases have been reported to develop 17 years or more after the primary lesion is removed (9). Although renal cell carcinoma may involve any organ, synchronous or metachronous urinary bladder metastasis is rare. Most metastases appear within one year (10). Synchronous solitary bladder metastasis from RCC is extremely rare. Synchronous detection of solitary metastasis with primary tumor is also considered as an unfavorable feature (11). Most patients with RCC metastasized to the bladder die within the first year of diagnosis $(5,10)$. It has been reported that patients presenting with a primary and metastatic lesion at the same time do not do as well as patients who present with metastasis after nephrectomy. The prognosis is uniformly poor in patients presenting with the primary and secondary lesion together, regardless of the mode of the therapy (11). Although there have been several longterm survivors (10), an average survival of 4 months may be expected in patients with synchronous metastases and only $10 \%$ will survive for one year (12).

Rodriguez et al. reported that the survival time in patients who developed a solitary metastasis after surgical removal of the primary tumor was better than those who exhibited a solitary metastasis in the presence of a primary tumor (6). In contrast, Manabu et al. reported that the mean survival time was 17.5 months for synchronous urinary bladder metastasis and 15.8 months for metachronous urinary metastasis. They suggested that the prognosis was not related to the interval between nephrectomy and the appearance of urinary bladder metastasis (8).

Almost all studies recommend surgical resection in the presence of solitary urinarybladder metastases. On the other

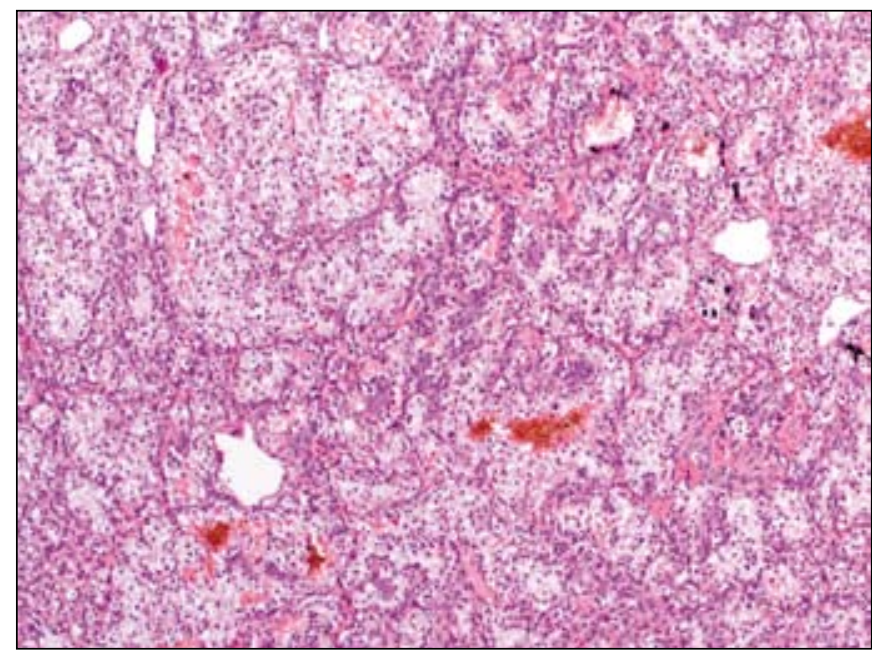

Figure 3: Renal cell carcinoma (H\&E, x100). 
hand, immunoreactive cytokines have been the mainstay of treatment of metastatic RCC. Interferon is one of the cytokines known to be effective against RCC. Shiraishi et al.
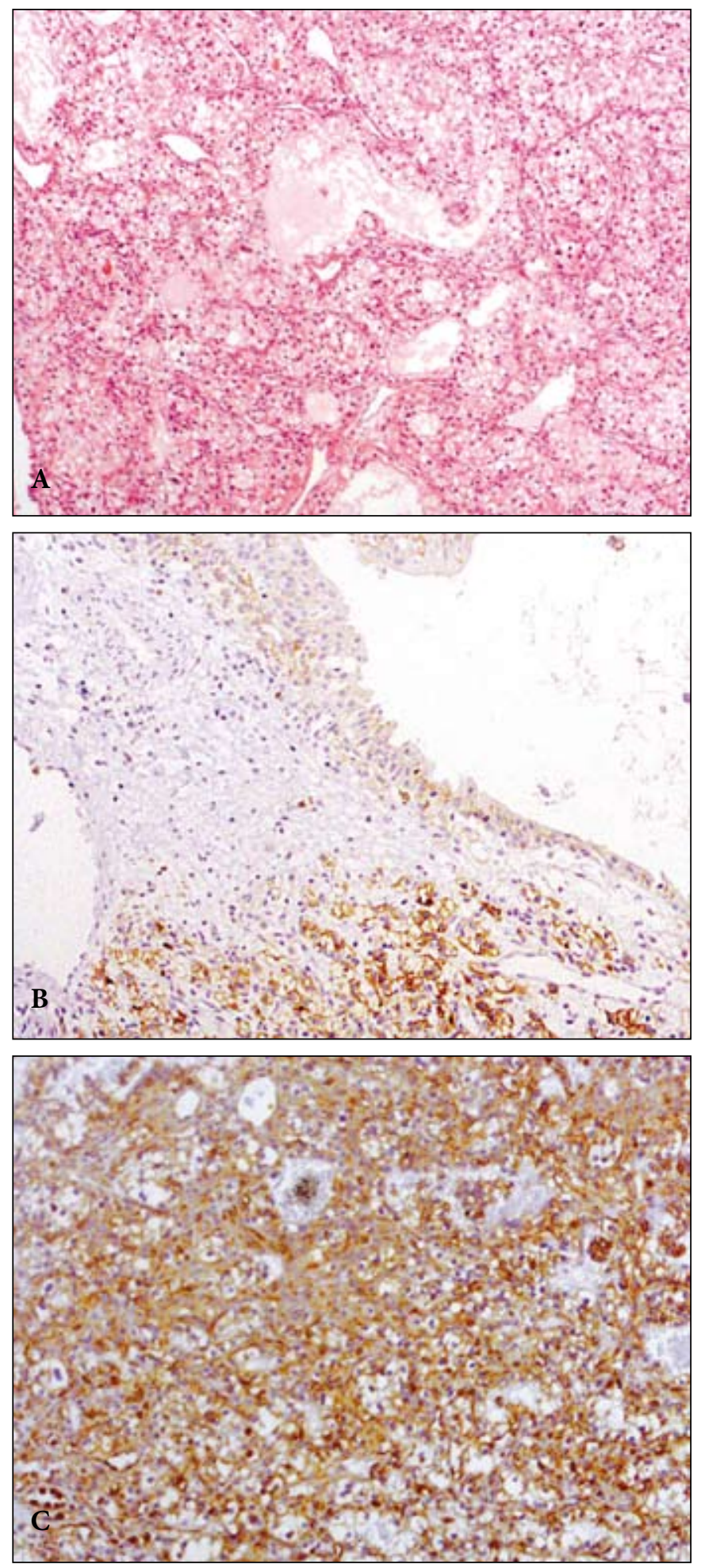

Figure 4: Metastatic renal cell carcinoma in the bladder (A: $\mathrm{H} \& \mathrm{E}, \mathrm{x} 100$; B: Keratin immunoreactivity, and C: Vimentin immunoreactivity; $\mathrm{x} 200)$.
(10) have proposed that additional systemic therapy against metastasis should be performed in most cases. In their study, progression of another metastasis was suggested to be manageable and long-term survival possible in combination with surgical resection and immunostimulant therapy used in an outpatient setting. The long-term survival obtained in our patient after resection may be explained by the association with immunotherapy. Surgical resection should therefore not be considered the only therapeutic tool against urinary bladder metastasis from RCC. A combined therapy should also be considered in the treatment of a solitary synchronous metastasis from RCC.

In conclusion, although rare, RCC can metastasize to the urinary bladder. The case reported here confirms that the unusual sites of metastasis from RCC should be considered. A combination of surgery with medical treatment should be considered in all patients with metastatic renal cell carcinoma since combined therapy may induce synergic antitumor activity. Investigation of this intriguing topic in the near future would be interesting.

\section{REFERENCES}

1. Slaton W, Swanson DA: Surgical resection of metastases. In: A. Belledegrun (Ed) Renal and Adrenal Tumors, Oxford, Oxford University Press, 2003, 436-446

2. Zerbi A, Ortolano E, Balzano G, Borri A, Beneduce AA, Di Carlo V: Pancreatic metastasis from renal cell carcinoma: which patients benefit from surgical resection? Ann Surg Oncol 2008, 15(4):1161-1168

3. Dogra P, Kumar A, Singh A: An unusual case of Von Hipple Lindau (VHL) syndrome with bilateral mutlicentric renal cell carcinoma with synchronous solitary urinary bladder metastasis. Int Urol Nephrol 2007, 39:11-14

4. Nakanishi Y, Arisawa C, Ando M: Solitary metastasis to the urinary bladder from renal cell carcinoma: a case report. Hinyokika Kiyo 2006, 52:937-939

5. Gallmetzer J, Gozzi C, Mazzoleni G: Solitary synchronous bladder metastasis from renal cell carcinoma treated by transurethral resection] Urologe A 2000, 39:52-54

6. Rodriguez A, Kang L, Politis C, Wade M, Sexton WJ, MirandaSousa A, Pow-Sang JM: Delayed metastatic renal carcinoma to prostate. Urol 2006, 67(3):623.e7-10

7. Kavolius JP, Mastorakos DP, Pavlovich C, Russo P, Burt ME, Brady MS: Resection of metastatic renal cell carcinoma. J Clin Oncol 1998, 16:2261-2266

8. Matsuo M, Koga S, Nishikido M, Noguchi M, Sakaguchi M, Nomata K, Maruta N, Hayashi T, Kanetake H: Renal cell carcinoma with solitary metachronous metastasis to the urinary bladder. Urol 2000, 60: 911xiii-911xiv

9. Coppa GF, Oszczakiewicz M: Parotid gland metastasis from renal carcinoma. Int Surg 1990, 75:198-202

10. Shiraishi K, Mohri J, Inoue $R$ and Kamiryo Y: Metastatic renal cell carcinoma to the bladder 12 years after radical nephrectomy. Int J Urol 2003, 10:453-455

11. O'Dea MJ, Zincke H, Utz DC, Bernatz PE: The treatment of renal cell carcinoma with solitary metastasis. J Urol 1978, 120:540-542

12. Maldazys JD, de Kernion JB: Prognostic factors in metastatic renal carcinoma. J Urol 1986, 136:376-379 